\title{
European Federation of Societies for Ultrasound in Medicine and Biology (EFSUMB) Policy Document Development Strategy - Clinical Practice Guidelines, Position Statements and Technological Reviews
}

\section{(이 (1) (요 $\odot$}

\author{
Authors \\ Christian Jenssen ${ }^{1}$, Odd Helge Gilja ${ }^{2}$, Andreas L. Serra ${ }^{3}$, Fabio Piscaglia ${ }^{4}$, Christoph F. Dietrich ${ }^{5}$, Lynne Rudd ${ }^{6}$, \\ Paul S. Sidhu' ${ }^{7}$
}

\section{Affiliations}

1 Krankenhaus Märkisch Oderland Strausberg/Wriezen, Klinik für Innere Medizin, Wriezen, Germany

2 National Centre for Ultrasound in Gastroenterology, Haukeland University Hospital, Bergen, Norway

3 Klinik Hirslanden, Department of Internal Medicine and Nephrology, Zurich, Switzerland

4 Div. Internal Medicine, Dept of Medical and Surgical Sciences, Bologna, Italy

5 Caritas-Krankenhaus, Medizinische Klinik 2, Bad Mergentheim, Germany

6 European Federation of Societies for Ultrasound in Medicine and Biology (EFSUMB), General Secretary, London, United Kingdom of Great Britain and Northern Ireland

7 King's College London, Radiology, London, United Kingdom of Great Britain and Northern Ireland

Key words

evidence, ultrasound, clinical practice guidelines, technological reviews, position statements

received $\quad 07.06 .2018$

revised $\quad 07.06 .2018$

accepted $\quad 10.10 .2018$

Bibliography

DOI https://doi.org/10.1055/a-0770-3965

Ultrasound Int Open 2019; 5: E2-E10

(c) Georg Thieme Verlag KG Stuttgart · New York

ISSN 2199-7152

Correspondence

Dr. Christian Jenssen

Krankenhaus Märkisch Oderland Strausberg/ Wriezen,

Klinik für Innere Medizin

Sonnenburger Weg 3-11

16629 Wriezen

Germany

Tel.: +49/334/5640 303, Fax: +49/334/5640 302

c.jenssen@khmol.de

\section{ABSTRACT}

This document summarizes principles and methodology to guide the creation of Clinical Practice Guidelines, Position Statements und Technological Reviews of the European Federation of Societies for Ultrasound in Medicine and Biology (EFSUMB). The purpose of EFSUMB Clinical Practice Guidelines is to provide physicians and sonographers performing or requesting diagnostic and interventional ultrasound examinations with evidence-based recommendations. Position Statements summarize EFSUMB opinions on important current issues in clinical applications, education and training of ultrasound techniques or health care policy related to ultrasound-based imaging and ultrasound-guided interventions. The third type of EFSUMB policy document is the Technological Review, which describes ultrasound techniques and technologies for physicians, medical technicians, engineers and physicists developing ultrasound technology. The whole process of development of EFSUMB policy documents is explained beginning with the decision regarding topics, selection of authors, funding, and planning of the developmental process. Further steps described in this document are the review of the evidence, creation of recommendations, statements and comments, grading of level of evidence and strength of recommendations, and consensus process. Finally, rules for the creation, review, approval, publication and update of EFSUMB policy documents are described. 


\section{Introduction}

Since 2004, the European Federation of Societies for Ultrasound in Medicine and Biology (EFSUMB) has published a variety of guidelines, recommendations and other policy documents concerning ultrasound. These documents are freely available at the EFSUMB website (www.efsumb.org) [1]. In particular, contrast-enhanced ultrasound (CEUS) guidelines were first introduced by EFSUMB in 2004 [2], and extended and updated in 2008 [3], 2011-2013 [4-7], and 2017/2018 [8]. The EFSUMB elastography guidelines were published in 2013 [9, 10] with an update started in 2017 [11, 12]. In 2015 and 2016, a series of guidelines on interventional ultrasound was released [13-24], followed by guidelines on gastrointestinal ultrasound, the first published in 2017 [25, 26].

The methodology of guideline development has developed over the last years, and several approaches to grade the quality of evidence as well as the strength of recommendations have emerged [27-42]. Acknowledging that quality, integrity and impact of clinical practice guidelines vary considerably, several academic institutions have suggested standards and criteria for "trustworthy clinical guidelines" as well as instruments for their evaluation [34, 35, 39, 40, 43-47].

Therefore, EFSUMB has summarized principles and methodology to guide the process of creating EFSUMB policy documents. This document was approved by the Executive Bureau (ExB) of EFSUMB on January 12, 2018.

\section{EFSUMB policy documents}

\section{Clinical practice guidelines}

The purpose of the EFSUMB Clinical Practice Guidelines (CPGs) is to provide physicians and sonographers performing or requesting diagnostic and interventional ultrasound examinations with evidence-based recommendations. The CPGs provide guidance on clinically relevant ultrasound-based imaging and ultrasound-guided interventions derived from reliable scientific literature applying a formal guideline developmental process according to the Appraisal of Guidelines for Research \& Evaluation II (AGREE II) criteria [34].

\section{Position statements}

Position Statements (PSs) are summarizing EFSUMB opinions on important current issues in clinical applications, education and training of ultrasound techniques or health care policy related to ultrasound-based imaging and ultrasound-guided interventions, when robust scientific evidence is lacking, long-term considerations are not possible or a formal guideline development process was not performed.

\section{Technological reviews}

Technological Reviews (TRs) describe in detail ultrasound techniques and technologies for physicians, medical technicians, engineers and physicists developing ultrasound technology, thus supporting and providing services in the field of ultrasound. If sufficient data are available, TRs should be evidence-based.

\section{Decision Process}

The steps to policy document creation are detailed as follows.

\section{Suggestion of topics}

Suggestions for CPGs, PSs and TRs can be made by members of the EFSUMB ExB, the committees of EFSUMB, members of the editorial board of Ultraschall in der Medizin/European Journal of Ultrasound, and the delegates/boards of the member societies. The ExB will also consider suggestions from other European/International medical societies cooperating with EFSUMB in the development of a policy document.

These proposals are subject to review by the EFSUMB ExB, and a final decision is reached by consensus of the ExB.

Suggestions to develop EFSUMB CPG/PS/TR should include:

- the main topic,

- a description of the overall objective(s) and clinical/technical questions to be covered,

- a short explanatory statement (target users, rationale to have a specific EFSUMB position on this topic).

\section{Decision regarding EFSUMB policy documents}

The ExB will review the suggestions and make a formal decision for approval based on the following criteria:

- relevance for the health care system, clinical medicine and imaging/ultrasound in particular,

- the potential and necessity to change current clinical practice, to improve quality or to reduce variability in performance,

- the urgency of the topic,

- useful co-operation with other national or international scientific societies or institutions in development,

- potentially already existing current CPGs/PSs/TRs of national or international scientific societies covering the topic,

- available evidence,

- resources and potential financial support.

If not approved, reasons will be given and there will be no appeal process.

Following approval of a suggested topic, ExB will decide on the type and central topic of the policy document, main author, leader and members of the Steering Committee and will suggest potential partnerships and document target time frames. Appointment of a Steering Committee is essential to manage the development process of a CPG, but may be dispensable for PS and TR.

\section{Development Process}

\section{Initiation}

To initiate the process of policy document development, the Steering Committee (CPR) or the main author (PS and TR) will

- create a disposition of the policy document,

- summarize objectives, methodology and main issues in a short abstract,

- select key questions,

- select and invite experts/authors for the guideline working group,

- assign the central issues and related key questions to subgroups/task forces of authors. 


\section{Authors/ experts}

The potential authors are selected based on their expertise (specialty knowledge, scientific publications, practical experience) related to the topic and/or particular issues of the guideline, and their freedom from major conflicts of interest (COIs). To assure the greatest possible inclusion of specific experience and practice patterns from different European health care systems, membership of the authors' group should be balanced between national member societies of EFSUMB. Therefore, the EFSUMB ExB will make the final decision regarding the composition of the authors' group.

Prior to initiation of the developmental process, the invited experts including the main author and all members of the Steering Committee are required to declare any potential COls, by completing and signing a separate COI questionnaire. A COI potentially may occur when an author has financial, commercial, legal, or professional relationships with companies/other organizations which are related to the topic or to key questions/issues of the policy paper and therefore could influence their appraisal of published evidence and judgement on statements/recommendations. Examples of potential COls are: stock or share ownership, patents/royalties, employment, membership in advisory boards, speakers and consultancy honoraria, research grants, membership in advocacy groups.

Potential COls of the main author and the members of the Steering Committee are evaluated by the ExB and recorded for inspection. The Steering Committee is obliged to evaluate the potential impact of disclosed COls of the authors on the process of guideline development. Significant potential COls (e. g., ownership interests or employment by a company with products related to the topics of the guideline) will preclude membership in the expert group and authorship of the guideline. All potential (modest or significant) COls will be disclosed in connection with the guideline document.

EFSUMB will not provide honoraria to the members of the Steering Committee and the expert group/authors, but it will cover expenses for travel and accommodation according to the bylaws of EFSUMB.

\section{Funding}

All pharmaceutical/medical-technical companies marketing products related to the topic of the policy document may be invited by the EFSUMB ExB to support the process of policy document development by funding this specific endeavor. The process should be supported by several companies; support from only a single company is not acceptable. Financial support of companies or foundations for the development and/or publication of EFSUMB CPGs/PSs/ TRs must not have any preconditions and should aim only to provide resources for the physical meeting of the selected members of the guidelines group. Representatives of medical/technical companies and foundations supporting EFSUMB financially are not allowed to take an active part in the process of guideline development and the consensus process, but may be consulted as external experts, if appropriate. There will be disclosure of details of any financial support in all policy documents.

\section{Review of the evidence}

For each key question, the authors will perform a systematic literature search based on an explicit search strategy using Medline,
Cochrane library and, if appropriate, further defined databases/ sources.

The search strategy is predefined with regard to sources (e. g., Medline), inclusion criteria (e. g., language of the publication, time period, study type, full publication) and exclusion criteria (e. g., single case reports, small case series, published only in abstract form), search terms (e. g., Medical Subject Headings, MESH terms).

For CPGs, evidence used to substantiate recommendations should be summarized in evidence tables including information on study type (e. g., systematic review and meta-analysis, randomized control trial [RCT], prospective/retrospective cohort study with defined outcome parameters, case series), case numbers, important outcomes and limitations. Quality of the included diagnostic studies is assessed with regard to methodology (e. g., patient selection, reference standard, study type), results (e. g., significance, confidence intervals), possible bias, conclusions and applicability to the key question.

\section{Preparation of recommendations, statements and comments}

After assimilating and reviewing the data, the members of the assigned task forces will draft recommendations and statements. Evidence tables, first drafts of recommendations or statements for one key question are primarily provided by one author, revised by the other members of the dedicated author groups and reviewed by the subgroup leaders. After approval by the subgroup members, the revised drafts are submitted to the whole expert group approximately 4 weeks before the expert meeting [13]. In the case of competing proposals for recommendations and statements, an electronically based Delphi process [27, 28, 31, 38, 41] may be used to prioritize one proposal over the others.

Depending on the quality of available data and the type of the respective policy document, recommendations and statements may be evidence-based or consensus-based.

Recommendations give specific and precise advice as to which particular procedure or technique under what circumstances should be preferred, whereas statements describe issues related to the key questions without giving action advice. Recommendations and statements should be explicitly linked to the supporting evidence, if available. Whenever available, systematic reviews should be used to support CPG recommendations.

\section{Clinical practice guidelines}

The results of the systematic literature search are discussed within the task forces in order to prepare preferably evidence-based and clinically well-balanced recommendations and statements on the assigned key questions and short comments constituting the recommendations and statements. For evidence-based recommendations or statements, the level of evidence, the level of expert agreement (recommendations and statements) and the strength of recommendation (only recommendations) are disclosed. For consensus-based recommendations and statements, only the level of agreement should be reported.

Comments briefly summarize and critically evaluate the available evidence (quantity, quality, consistency), and their clinical relevance and applicability. They include a description of potential benefits and harms of the recommended action. 


\section{Position statements}

A comprehensive literature search is performed to identify relevant studies. However, rating the level of evidence and strength of recommendations will not be performed, and recommendations will be based on expert consensus. The level of agreement is reported. Again, short comments are prepared to explain the reasoning underlying recommendations and statements.

\section{Technological reviews}

Based on published studies, which have been identified by a comprehensive literature search, TRs describe and assess particular techniques or devices without giving formal recommendations and statements.

\section{Grading the quality of evidence and the strength of recommendations}

For CPGs, grading the quality of evidence and the strength of recommendations is mandatory. For that purpose, previous and ongoing EFSUMB guidelines have used the Oxford Centre for Evidence-Based Medicine (OCEBM) Levels of Evidence (Version 1, first released in 2000 and last updated in 2009), which are based on the assessment of type and quality of study design [33]. According to this approach, levels of evidence (LoE) were graded 1-5 considering the traditional pyramid of evidence placing meta-analysis and systematic reviews categorically on the top of the hierarchy above RCT and observational studies [48]. Grades of Recommendation (GoR) A-D were allocated closely following LoE with a narrow scope for up- or downgrades. According to OCEBM Levels of Evidence Version 1, Grade A recommendations have been derived from LoE 1 evidence supporting a decision that should apply to the majority of patients in most circumstances. Recommendations have been graded GoR B or C if derived from level 2 or 3 evidence, if level 1 or 2 evidence was not consistent ("majority evidence") or was only indirect with regard to the recommendation ("extrapolation”). The GoR was upgraded if there was a great body of homogeneous evidence directly related to the respective key question. Expert opinion and "good clinical practice" were graded LoE 5 [13].

More recent evidence-ranking schemes such as Grading of Recommendations Assessment, Development and Evaluation (GRADE, 2008) and version 2 (2011) of OCEBM LoE are less rigid with regard to ranking evidence, simplify classifications, and allow appraisal of other important factors like consistency of published studies, estimate of clinical benefit, risk, cost efficiency, patient values and preferences, ethical issues, equity, accessibility, and feasibility in clinical practice [29, 30, 32, 36, 37, 47, 49-52].

To facilitate a more feasible and complex appraisal of existing evidence, to be consistent with the previous approach, and to simplify the classification of the strength of recommendations, the EFSUMB ExB has specified that this new strategy will be adopted for upcoming policy documents. The LoE will be rated according to the 2011 OCEBM approach which, like the 2009 version, advises appraisal of evidence from different fields of medicine: prevalence, accuracy of clinical diagnostics, prognosis, therapeutic effects, common and rare harms, and usefulness of screening ( [36]. The new OCEBM version allows downgrading of the LoE because of limitations in study quality, indirectness with regard to the key question, inconsistency between study results, or small effect size. Conversely, upgrade is possible if the estimate of clinical effect is large [36]. Classification of the strength of recommendations will be simplified by using the GRADE approach, which considers both the quality of evidence and the risks, benefits, and costs of the recommended approach $[29,49,53,54]$. When classifying a recommendation either as strong or weak, in addition to the LoE, the expert group has to take into account the expected estimates of clinical benefit and risk of the recommended intervention, its cost efficiency, patient values and preferences, ethical issues, and feasibility in clinical practice. A recommendation is classified as "strong" (possible wording: "EFSUMB recommends") if the benefits clearly outweigh the risks or burden (or vice versa) and if it applies to the majority of patients in most circumstances. A recommendation is classified as "weak" (possible wording: "EFSUMB suggests") if the difference between desirable and undesirable effects is relatively small or uncertain, and, therefore, decisions in individual cases may be influenced by a variety of variables ( $\triangleright$ Table 2 ) $[32,47,49,52,54-57]$.

\section{Consensus process and meetings}

A consensus meeting is planned approximately 6 months after initiation of a policy document development, in line with the time frame stipulated by the ExB at the start of the process. The task force should have finished the process of drafting and approving recommendations, statements, evidence tables and comments related to their respective key questions approximately 4 weeks prior to the fixed date of the consensus meeting, and communicated these drafts electronically to the members of the whole expert group for critical evaluation.

The consensus meeting for CPGs should be a face-to-face meeting. Electronically based voting is possible if the participants of the consensus meeting decide that a particular recommendation/statement has to be rephrased by the responsible task force or prior to the consensus meeting to evaluate different versions of a recommendation or statement (Delphi process) [31, 38, 39, 41]. As an alternative to a meeting in person, video conferences and/or electronically based voting may be used for PSs and for partial updates of CPGs. For TRs the consensus process will normally be electronically based.

At the consensus meeting

- the prepared recommendations and statements as well as the related evidence are presented by the task force members,

- all significant unresolved or controversial issues and the quality of evidence and strength of recommendations are discussed,

- the recommendations and statements are approved by voting by all members of the expert group.

Individual members of the expert group may abstain from voting on any individual recommendation or statement in the case of potential COls or inadequate knowledge related to the particular issue.

A recommendation or statement is approved if $>75 \%$ of voting members are in agreement (broad agreement: $>75-95 \%$ of votes; strong consensus: $\geq 95 \%$ of votes) [13]. If $>50-75 \%$ of votes are in favor of a recommendation or statement (majority consensus), a rephrased or an alternative draft will be voted on after a discussion. For discussion a nominal group technique is applied [31, 38, 39, 41]. In the case of primary disagreement ( $\leq 50 \%$ of votes or less in favor) 
- Table 1 Rating the levels of evidence (LoE) for EFSUMB CPGs based on the Oxford Center of Evidence-Based Medicine (OCEBM) system, version 2 (2011; modified from [36]).

\begin{tabular}{|c|c|c|c|c|c|}
\hline Clinical question & LoE 1* & LoE 2* & LoE $3^{*}$ & LoE 4* & LoE $5^{*}$ \\
\hline $\begin{array}{l}\text { How common is the } \\
\text { problem? }\end{array}$ & $\begin{array}{l}\text { Local and current } \\
\text { random sample surveys } \\
\text { (or censuses) }\end{array}$ & $\begin{array}{l}\text { Systematic review of } \\
\text { surveys that allow } \\
\text { matching to local } \\
\text { circumstances** }\end{array}$ & $\begin{array}{l}\text { Local non-random } \\
\text { sample** }^{* *}\end{array}$ & Case series** & Not applicable \\
\hline $\begin{array}{l}\text { Is this diagnostic test } \\
\text { accurate? } \\
\text { (Diagnosis) }\end{array}$ & $\begin{array}{l}\text { Systematic review of } \\
\text { cross-sectional studies } \\
\text { with consistently applied } \\
\text { reference standard and } \\
\text { blinding }\end{array}$ & $\begin{array}{l}\text { Individual cross-section- } \\
\text { al study with consist- } \\
\text { ently applied reference } \\
\text { standard and blinding }\end{array}$ & $\begin{array}{l}\text { Non-consecutive studies, } \\
\text { or studies without } \\
\text { consistently applied } \\
\text { reference standards** }\end{array}$ & $\begin{array}{l}\text { Case control studies or } \\
\text { poor or non-independ- } \\
\text { ent reference } \\
\text { standard }^{* *}\end{array}$ & $\begin{array}{l}\text { Mechanism-based } \\
\text { reasoning }\end{array}$ \\
\hline $\begin{array}{l}\text { What will happen if } \\
\text { we do not add a } \\
\text { therapy? } \\
\text { (Prognosis) }\end{array}$ & $\begin{array}{l}\text { Systematic review of } \\
\text { inception cohort studies }\end{array}$ & Inception cohort studies & $\begin{array}{l}\text { Cohort study or control } \\
\text { arm of randomized trial** }\end{array}$ & $\begin{array}{l}\text { Case series or case } \\
\text { control studies or poor } \\
\text { quality prognostic } \\
\text { cohort study** }^{*}\end{array}$ & Not applicable \\
\hline $\begin{array}{l}\text { Does this interven- } \\
\text { tion help? } \\
\text { (Treatment Benefits) }\end{array}$ & $\begin{array}{l}\text { Systematic review of } \\
\text { randomized trials or } \\
n \text {-of- } 1 \text { trials }\end{array}$ & $\begin{array}{l}\text { Randomized trial or } \\
\text { observational study with } \\
\text { dramatic effect }\end{array}$ & $\begin{array}{l}\text { Non-randomized } \\
\text { controlled cohort/ } \\
\text { follow-up study** }\end{array}$ & $\begin{array}{l}\text { Case series, case } \\
\text { control studies, or } \\
\text { historically controlled } \\
\text { studies** }^{* *}\end{array}$ & $\begin{array}{l}\text { Mechanism-based } \\
\text { reasoning }\end{array}$ \\
\hline $\begin{array}{l}\text { What are the } \\
\text { common harms? } \\
\text { (Treatment Harms) }\end{array}$ & $\begin{array}{l}\text { Systematic review of } \\
\text { randomized trials, } \\
\text { systematic review of } \\
\text { nested case control } \\
\text { studies, } n \text {-of- } 1 \text { trial with } \\
\text { the patient you are } \\
\text { raising the question } \\
\text { about, or observational } \\
\text { study with dramatic } \\
\text { effect }\end{array}$ & $\begin{array}{l}\text { Individual randomized } \\
\text { trial or (exceptionally) } \\
\text { observational study with } \\
\text { dramatic effect }\end{array}$ & $\begin{array}{l}\text { Non-randomized } \\
\text { controlled cohort/ } \\
\text { follow-up study } \\
\text { (post-marketing } \\
\text { surveillance) provided } \\
\text { there are sufficient } \\
\text { numbers to rule out a } \\
\text { common harm (for } \\
\text { long-term harms the } \\
\text { duration of follow-up } \\
\text { must be sufficient) }\end{array}$ & $\begin{array}{l}\text { Case series, case } \\
\text { control studies, or } \\
\text { historically controlled } \\
\text { studies** }\end{array}$ & $\begin{array}{l}\text { Mechanism-based } \\
\text { reasoning }\end{array}$ \\
\hline $\begin{array}{l}\text { What are the rare } \\
\text { harms? } \\
\text { (Treatment Harms) }\end{array}$ & $\begin{array}{l}\text { Systematic review of } \\
\text { randomized trials or } \\
n \text {-of- } 1 \text { trial }\end{array}$ & $\begin{array}{l}\text { Randomized trial or } \\
\text { (exceptionally) } \\
\text { observational study with } \\
\text { dramatic effect }\end{array}$ & & & \\
\hline $\begin{array}{l}\text { Is this (early } \\
\text { detection) test } \\
\text { worthwhile? } \\
\text { (Screening) }\end{array}$ & $\begin{array}{l}\text { Systematic review of } \\
\text { randomized trials }\end{array}$ & Randomized trial & $\begin{array}{l}\text { Non-randomized } \\
\text { controlled cohort/ } \\
\text { follow-up study** }\end{array}$ & $\begin{array}{l}\text { Case series, case } \\
\text { control studies, or } \\
\text { historically controlled } \\
\text { studies** }^{*}\end{array}$ & $\begin{array}{l}\text { Mechanism-based } \\
\text { reasoning }\end{array}$ \\
\hline
\end{tabular}

or if the rephrased or alternative recommendation or statement again fails to gain $>75 \%$ of votes, the recommendation or statement will be removed. A lack of consent on this particular issue/ key question will be recorded in the text of the policy document $(\triangleright$ Table 3).

\section{Outline and Review of the Manuscript}

\section{Structure of the policy document}

EFSUMB policy documents will include the following elements:

- title specifying the topic and the particular type of policy document,
- list of authors and affiliations,

- representative abstract, structured for the target publication

- main body of text including introduction, methodology, topics/key questions of task forces as section headings, recommendations/statements (only CPGs and PSs) followed by comments/discussion, tables,

- references,

- authors' disclosure of potential CIOs,

- publication date and expiration date/announcement of intended update,

- appendix (e. g., algorithms, evidence tables, glossary, tables of task force members, acknowledgements, legal disclaimer). 
- Table 2 Strength of recommendations in EFSUMB CPGs according to GRADE: Interpretation, evaluation criteria, wording, and implications (criteria modified from [47, 53-57]).

\begin{tabular}{|c|c|c|}
\hline & Strong recommendation & Weak recommendation \\
\hline \multicolumn{3}{|l|}{ Interpretation } \\
\hline General meaning & $\begin{array}{l}\text { Clear preference for or against one alternative course } \\
\text { of action. } \\
\text { Recommendation applies for almost all patients. }\end{array}$ & $\begin{array}{l}\text { Closer balance between desirable and undesirable } \\
\text { consequences of alternative strategies. } \\
\text { Recommendation may be conditional upon } \\
\text { - Patient values and preferences } \\
\text { - The resources available } \\
\text { - The setting in which the intervention/technique will } \\
\text { be implemented. }\end{array}$ \\
\hline $\begin{array}{l}\text { For a particular intervention } \\
\text { (Positive recommendation) }\end{array}$ & $\begin{array}{l}\text { Estimate of effect is large. } \\
\text { Desirable effects clearly outweigh undesirable ones. }\end{array}$ & $\begin{array}{l}\text { Estimate of effect is small. } \\
\text { Desirable effects likely or slightly outweigh undesirable } \\
\text { ones. }\end{array}$ \\
\hline $\begin{array}{l}\text { Against a particular intervention } \\
\text { (Negative recommendation) }\end{array}$ & $\begin{array}{l}\text { Disadvantages/risks of an intervention/technique are } \\
\text { substantial. } \\
\text { Undesirable effects clearly outweigh desirable ones. }\end{array}$ & $\begin{array}{l}\text { Disadvantages/risks of an intervention/technique are } \\
\text { mentionable. } \\
\text { Undesirable effects likely or slightly outweigh desirable } \\
\text { ones. }\end{array}$ \\
\hline \multicolumn{3}{|c|}{ Criteria to evaluate strength of recommendation } \\
\hline $\begin{array}{l}\text { Difference between benefits and harms } \\
\text { or burden }\end{array}$ & High net benefit or harm. & Low net benefit or harm. \\
\hline Level of evidence & $\begin{array}{l}\text { High (LoE } 1 \text { and 2). } \\
\text { High level of certainty about the magnitude of } \\
\text { particular desirable and undesirable consequences of } \\
\text { the recommended intervention/technique. }\end{array}$ & $\begin{array}{l}\text { Low (LoE } 3 \text { and } 4 \text { ). } \\
\text { Low level of certainty about the magnitude of particular } \\
\text { desirable and undesirable consequences of the } \\
\text { suggested intervention/technique. }\end{array}$ \\
\hline $\begin{array}{l}\text { Values and preferences that patients } \\
\text { assign to outcomes of interest }\end{array}$ & Low variability or uncertainty. & High variability or uncertainty. \\
\hline Resource implications & $\begin{array}{l}\text { Required resources are lower than for alternative } \\
\text { strategy. } \\
\text { Reasonable cost-efficiency. }\end{array}$ & $\begin{array}{l}\text { Required resources are higher than for alternative } \\
\text { strategy. } \\
\text { Debatable cost-efficiency. }\end{array}$ \\
\hline Feasibility, accessibility, equity & $\begin{array}{l}\text { Recommended intervention/technique is feasible, } \\
\text { widely available and accessible. } \\
\text { Inequities in health care are reduced or health equity } \\
\text { is promoted. }\end{array}$ & $\begin{array}{l}\text { Feasibility, availability and/or accessibility of the } \\
\text { suggested intervention/technique are limited. } \\
\text { Particular groups of patients or settings might be } \\
\text { disadvantaged with regard to the suggested interven- } \\
\text { tion/technique. }\end{array}$ \\
\hline \multicolumn{3}{|l|}{ Possible wording } \\
\hline $\begin{array}{l}\text { Positive recommendation } \\
\text { (for a particular intervention/technique) }\end{array}$ & $\begin{array}{l}\text { „EFSUMB recommends ..." } \\
\text { “... should be performed." }\end{array}$ & $\begin{array}{l}\text { "EFSUMB suggests ...." } \\
\text { "... might be performed." }\end{array}$ \\
\hline $\begin{array}{l}\text { Negative recommendation } \\
\text { (against a particular intervention/ } \\
\text { technique) }\end{array}$ & $\begin{array}{l}\text { „EFSUMB recommends against “ } \\
\text { “... should not be performed.” }\end{array}$ & $\begin{array}{l}\text { "EFSUMB suggests ...." } \\
\text { "... might not be performed." } \\
\text { Comment should give an explanation about the issues } \\
\text { that would cause decisions to vary. }\end{array}$ \\
\hline Implications for target groups & Uniformity of choice. & Variability of choice. \\
\hline Patients & $\begin{array}{l}\text { Almost all informed patients would make the } \\
\text { recommended choice for or against an intervention. }\end{array}$ & $\begin{array}{l}\text { The majority of informed patients would choose the } \\
\text { suggested intervention/technique, but a substantial } \\
\text { number would not. }\end{array}$ \\
\hline Physicians & $\begin{array}{l}\text { The recommended intervention/technique should be } \\
\text { applied in most patients. }\end{array}$ & $\begin{array}{l}\text { Different choices will be appropriate depending on } \\
\text { particular patient characteristics and settings. } \\
\text { Greater effort should be made to help an individual } \\
\text { patient to come to a decision consistent with his/her } \\
\text { own values and preferences. } \\
\text { Formal decision aids and shared decision-making are } \\
\text { particularly useful. }\end{array}$ \\
\hline Policy-makers & $\begin{array}{l}\text { The recommendation can be adopted as a policy in } \\
\text { most situations. } \\
\text { Variability in clinical practice between individuals or } \\
\text { regions may be inappropriate. } \\
\text { Recommendation is a potential candidate for quality } \\
\text { of care criterion. }\end{array}$ & $\begin{array}{l}\text { Substantial debate and involvement of many stakehold- } \\
\text { ers is necessary before a policy decision is made. } \\
\text { Variability in clinical practice between individuals or } \\
\text { regions may be acceptable. }\end{array}$ \\
\hline
\end{tabular}


- Table 3 Rules for approval of recommendations and statements for EFSUMB CPGs by consensus.

\begin{tabular}{|c|c|c|}
\hline Result of voting & $\begin{array}{l}\text { Percentage of votes in favor of the } \\
\text { statement/recommendation }\end{array}$ & Consequences \\
\hline Strong consensus & $>95 \%$ & Recommendation/statement is adopted. \\
\hline Broad agreement & $>75-95 \%$ & Recommendation/statement is adopted. \\
\hline Majority consensus & $>50-75 \%$ & $\begin{array}{l}\text { Discussion and attempt to rephrase the recommendation/statement using a } \\
\text { nominal group process. } \\
\text { A rephrased or an alternative recommendation/statement is voted on. } \\
\text { The rephrased or an alternative recommendation/statement is adopted } \\
\text { with }>75 \% \text { of votes. } \\
\text { A rephrased or alternative recommendation/statement is rejected with } \leq 75 \% \text { of } \\
\text { votes. Missing consent on the particular key question will be recorded and } \\
\text { explained in the text of the policy document. }\end{array}$ \\
\hline Primary disagreement & $\leq 50 \%$ & $\begin{array}{l}\text { The particular recommendation/statement is rejected and will not be published } \\
\text { in the policy document. } \\
\text { Voting on an alternative recommendation/statement on the particular key } \\
\text { question is possible. }\end{array}$ \\
\hline
\end{tabular}

Appendices and comments may be published in an online-only supplement. Only if the extent of the policy paper will compromise the capacity of a printed journal, the complete version may be published online-only in addition to a condensed printed version.

\section{External review}

The final document will be reviewed by two or three independent senior experts from EFSUMB or a learned body selected by the ExB, which may include such societies as WFUMB, who have not been previously involved in the guideline process. Peer review should include a check of the manuscript using the AGREE II 23-item instrument [34]. Any external reviewers will be invited by the EFSUMB ExB.

Suggestions to change any recommendations/statements will be discussed within the Steering Committee, and modified recommendations/statements will be approved using a Delphi process applying the same rules as used in the consensus meeting. Electronically based voting and Web-based consensus meetings may be used instead of personal meetings.

\section{Publication and Dissemination}

\section{Approval by the Executive Board and publication}

Following external review, the final edited versions of EFSUMB policy documents are forwarded by the Steering Committee to the EFSUMB ExB. Once adopted, in a timely fashion, by the EFSUMB ExB, the final version is submitted to a scientific ultrasound/imaging journal, preferentially to "Ultraschall in der Medizin/ European Journal of Ultrasound". Independently from the previous external review, EFSUMB policy papers will undergo a peer review process according to the common rules and standards of the scientific journal. In addition to the printed journal version, all EFSUMB policy documents along with the supplements will be published online at the EFSUMB website and will be freely available without restrictions.

\section{Dissemination}

Review articles, webinars and lectures at national and international ultrasound and imaging congresses summarizing and commenting on the EFSUMB policy documents are encouraged.

\section{Update}

Literature within the scope of the policy paper should be monitored by the Steering Committee (CPGs) or the main author (other policy documents) on a yearly basis to identify new evidence with potentially significant impact on recommendations and statements.

\section{Regular update}

A fixed date for regular revision of the policy document should be announced at the time of publication. An update is expected at least every five years for CPGs. Approximately one year before the policy document expires, the EFSUMB ExB should consider the initiation of an update process. Upon the recommendation of the Steering Committee or the responsible main author, the ExB decides to completely update the policy document, to revise only parts or to prolong the validity of the policy document for a definite time.

\section{Extraordinary updates}

In the event of new high-quality evidence fundamentally challenging one or more statements/recommendations, the Steering Committee will initiate an extraordinary revision of these particular recommendations/statements [58], which will be published on the EFSUMB website.

\section{Guideline Endorsement}

If a national or international scientific society requests EFSUMB endorsement for its own guideline, a small task force of experts appointed by the EFSUMB ExB will review the respective guideline with respect to compliance with EFSUMB's own policy papers and 
appropriate appreciation of sonographic techniques. Within 4 weeks, the task force will submit this review and its recommendation regarding endorsement to the ExB for final decision. The decision of the EFSUMB ExB and a short explanatory comment will be submitted to the requesting society.

\section{Conflict of Interest}

Christian Jenssen, Odd Helge Gilja, Andreas L. Serra, Fabio Piscaglia, Christoph F. Dietrich and Paul S. Sidhu are former or current members of the Executive Bureau of EFSUMB. Lynne Rudd is General Secretary of EFSUMB. All authors are involved in EFSUMB guideline development.

\section{References}

[1] Dietrich CF, Rudd L, Saftiou A, Gilja OH. The EFSUMB website, a great source for ultrasound information and education. Med Ultrason 2017; 19: $102-110$

[2] Albrecht T, Blomley M, Bolondi L, Claudon M, Correas JM, Cosgrove D, Greiner $L$ et al. Guidelines for the use of contrast agents in ultrasound. January 2004 Ultraschall Med 2004; 25: 249-256

[3] Claudon M, Cosgrove D, Albrecht T, Bolondi L, Bosio M, Calliada F, Correas JM et al. Guidelines and good clinical practice recommendations for contrast enhanced ultrasound (CEUS) - Update 2008. Ultraschall Med 2008; 29: 28-44

[4] Piscaglia F, Nolsoe C, Dietrich CF, Cosgrove DO, Gilja OH, Bachmann Nielsen M, Albrecht T et al. The EFSUMB Guidelines and Recommendations on the Clinical Practice of Contrast Enhanced Ultrasound (CEUS): Update 2011 on non-hepatic applications. Ultraschall Med 2012; 33: 33-59

[5] Dietrich CF, Averkiou MA, Correas JM, Lassau N, Leen E, Piscaglia F. An EFSUMB introduction into Dynamic Contrast-Enhanced Ultrasound (DCE-US) for quantification of tumour perfusion. Ultraschall Med 2012; 33: $344-351$

[6] Claudon M, Dietrich CF, Choi BI, Cosgrove DO, Kudo M, Nolsoe CP, Piscaglia $\mathrm{F}$ et al. Guidelines and good clinical practice recommendations for Contrast Enhanced Ultrasound (CEUS) in the liver - Update 2012: A WFUMB-EFSUMB initiative in cooperation with representatives of AFSUMB, AIUM, ASUM, FLAUS and ICUS. Ultrasound Med Biol 2013; 39: $187-210$

[7] Claudon M, Dietrich CF, Choi BI, Cosgrove DO, Kudo M, Nolsoe CP, Piscaglia F et al. Guidelines and good clinical practice recommendations for contrast enhanced ultrasound (CEUS) in the liver - Update 2012: A WFUMB-EFSUMB initiative in cooperation with representatives of AFSUMB, AIUM, ASUM, FLAUS and ICUS. Ultraschall Med 2013; 34: $11-29$

[8] Sidhu PS, Piscaglia F, Bartels E, Bertolotto M, Callida F, Cantisani V, Clevert DA et al. The EFSUMB guidelines and recommendations for the clinical practice of contrast enhanced ultrasound (CEUS) in non-hepatic applications: Update 2017. Ultraschall Med 2018; 39: accepted for publication

[9] Bamber J, Cosgrove D, Dietrich CF, Fromageau J, Bojunga J, Calliada F, Cantisani $V$ et al. EFSUMB guidelines and recommendations on the clinical use of ultrasound elastography. Part 1: Basic principles and technology. Ultraschall Med 2013; 34: 169-184

[10] Cosgrove D, Piscaglia F, Bamber J, Bojunga J, Correas JM, Gilja OH, Klauser AS et al. EFSUMB guidelines and recommendations on the clinical use of ultrasound elastography. Part 2: Clinical applications. Ultraschall Med 2013; 34: 238-253
[11] Dietrich CF, Bamber ], Berzigotti A, Bota S, Cantisani V, Castera L, Cosgrove $D$ et al. EFSUMB Guidelines and Recommendations on the Clinical Use of Liver Ultrasound Elastography, Update 2017 (Long Version). Ultraschall Med 2017; 38: e16-e47

[12] Dietrich CF, Bamber ], Berzigotti A, Bota S, Cantisani V, Castera L, Cosgrove $D$ et al. EFSUMB Guidelines and Recommendations on the Clinical Use of Liver Ultrasound Elastography, Update 2017 (Short Version). Ultraschall Med 2017; 38: 377-394

[13] Dietrich CF, Lorentzen T, Sidhu PS, Jenssen C, Gilja OH, Piscaglia F.Efsumb An Introduction to the EFSUMB Guidelines on Interventional Ultrasound (INVUS). Ultraschall Med 2015; 36: 460-463

[14] Lorentzen T, Nolsoe CP, Ewertsen C, Nielsen MB, Leen E, Havre RF, Gritzmann $N$ et al. EFSUMB Guidelines on Interventional Ultrasound (INVUS), Part I. General Aspects (long Version). Ultraschall Med 2015; 36: E1-E14

[15] Lorentzen T, Nolsoe CP, Ewertsen C, Nielsen MB, Leen E, Havre RF, Gritzmann N et al. EFSUMB Guidelines on Interventional Ultrasound (INVUS), Part I. General Aspects (Short Version). Ultraschall Med 2015; 36: 464-472

[16] Sidhu PS, Brabrand K, Cantisani V, Correas JM, Cui XW, D'Onofrio M, Essig M et al. EFSUMB Guidelines on Interventional Ultrasound (INVUS), Part II. Diagnostic Ultrasound-Guided Interventional Procedures (Long Version). Ultraschall Med 2015; 36: E15-E35

[17] Sidhu PS, Brabrand K, Cantisani V, Correas JM, Cui XW, D'Onofrio M, Essig M et al. EFSUMB Guidelines on Interventional Ultrasound (INVUS), Part II. Diagnostic Ultrasound-Guided Interventional Procedures (Short Version). Ultraschall Med 2015; 36: 566-580

[18] Dietrich CF, Lorentzen T, Appelbaum L, Buscarini E, Cantisani V, Correas JM, Cui XW et al. EFSUMB Guidelines on Interventional Ultrasound (INVUS), Part III - Abdominal Treatment Procedures (Long Version). Ultraschall Med 2016; 37: E1-E32

[19] Dietrich CF, Lorentzen T, Appelbaum L, Buscarini E, Cantisani V, Correas JM, Cui XW et al. EFSUMB Guidelines on Interventional Ultrasound (INVUS), Part III - Abdominal Treatment Procedures (Short Version). Ultraschall Med 2016; 37: 27-45

[20] Jenssen C, Hocke M, Fusaroli P, Gilja OH, Buscarini E, Havre RF, Ignee A et al. EFSUMB Guidelines on Interventional Ultrasound (INVUS), Part IV - EUS-guided Interventions: General aspects and EUS-guided sampling (Long Version). Ultraschall Med 2016; 37: E33-E76

[21] Jenssen C, Hocke M, Fusaroli P, Gilja OH, Buscarini E, Havre RF, Ignee A et al. EFSUMB Guidelines on Interventional Ultrasound (INVUS), Part IV - EUS-guided interventions: General Aspects and EUS-guided Sampling (Short Version). Ultraschall Med 2016; 37: 157-169

[22] Fusaroli P, Jenssen C, Hocke M, Burmester E, Buscarini E, Havre RF, Ignee A et al. EFSUMB Guidelines on Interventional Ultrasound (INVUS), Part V. Ultraschall Med 2016; 37: 77-99

[23] Fusaroli P, Jenssen C, Hocke M, Burmester E, Buscarini E, Havre RF, Ignee A et al. EFSUMB Guidelines on Interventional Ultrasound (INVUS), Part V - EUS-Guided Therapeutic Interventions (short version). Ultraschall Med 2016; 37: 412-420

[24] Jenssen C, Brkljacic B, Hocke M, Ignee A, Piscaglia F, Radzina M, Sidhu PS et al. EFSUMB Guidelines on Interventional Ultrasound (INVUS), Part VI - Ultrasound-Guided Vascular Interventions. Ultraschall Med 2016; 37: $473-476$

[25] Nylund K, Maconi G, Hollerweger A, Ripolles T, Pallotta N, Higginson A, Serra $C$ et al. EFSUMB Recommendations and Guidelines for Gastrointestinal Ultrasound. Ultraschall Med 2017; 38: e1-e15

[26] Nylund K, Maconi G, Hollerweger A, Ripolles T, Pallotta N, Higginson A, Serra $C$ et al. EFSUMB Recommendations and Guidelines for Gastrointestinal Ultrasound. Ultraschall Med 2017; 38: 273-284

[27] Murphy MK, Black NA, Lamping DL, McKee CM, Sanderson CF, Askham J, Marteau T. Consensus development methods, and their use in clinical guideline development. Health Technol Assess 1998; 2: i-iv 1-88 
[28] Black N, Murphy M, Lamping D, McKee M, Sanderson C, Askham ], Marteau T. Consensus development methods: A review of best practice in creating clinical guidelines. J Health Serv Res Policy 1999; 4 : 236-248

[29] Atkins D, Eccles M, Flottorp S, Guyatt GH, Henry D, Hill S, Liberati A et al. Systems for grading the quality of evidence and the strength of recommendations I: critical appraisal of existing approaches The GRADE Working Group. BMC Health Serv Res 2004; 4: 38

[30] Atkins D, Best D, Briss PA, Eccles M, Falck-Ytter Y, Flottorp S, Guyatt $\mathrm{GH}$ et al. Grading quality of evidence and strength of recommendations. BM] 2004; 328: 1490

[31] Hutchings A, Raine R, Sanderson C, Black N. A comparison of formal consensus methods used for developing clinical guidelines. J Health Serv Res Policy 2006; 11: 218-224

[32] Guyatt GH, Oxman AD, Vist GE, Kunz R, Falck-Ytter Y, Alonso-Coello P, Schunemann $\mathrm{HJ}$ et al. GRADE: An emerging consensus on rating quality of evidence and strength of recommendations. BMJ 2008; 336: 924-926

[33] Phillips B, Ball C, Sackett D, Badenoch D, Straus S, B. H Dawes M et al. Oxford Centre for Evidence-based Medicine - Levels of Evidence 1. In. Oxford: Oxford Centre for Evidence-Based Medicine; 2009

[34] Brouwers MC, Kho ME, Browman GP, Burgers JS, Cluzeau F, Feder G, Fervers B et al. AGREE II: advancing guideline development, reporting and evaluation in health care. J Clin Epidemiol 2010; 63: 1308-1311

[35] Graham R, Mancher M, D. MW S. G Steinberg E. (Editors) Clinical Practice Guidelines We Can Trust. Washington (DC): National Academies Press (US); 2011

[36] Howick J, Chalmers I, Glasziou P, Greenhalgh T, Heneghan C, Liberati A, Moschetti I et al. The Oxford Levels of Evidence 2. In. Oxford: Oxford Centre for Evidence-Based Medicine; 2011

[37] Howick J, Chalmers I, Glasziou P, Greenhalgh T, Heneghan C, Liberati A, Moschetti I et al Explanation of the 2011 Oxford Centre for EvidenceBased Medicine (OCEBM) Levels of Evidence (Background Document). In. Oxford: Oxford Centre for Evidence-Based Medicine; 2011

[38] Nair R, Aggarwal R, Khanna D. Methods of formal consensus in classification/diagnostic criteria and guideline development. Semin Arthritis Rheum 2011; 41: 95-105

[39] Qaseem A, Forland F, Macbeth F, Ollenschlager G, Phillips S, van der Wees P. Board of Trustees of the Guidelines International N. Guidelines International Network: toward international standards for clinical practice guidelines. Ann Intern Med 2012; 156: 525-531

[40] Schunemann HJ, Wiercioch W, Etxeandia I, Falavigna M, Santesso N, Mustafa R, Ventresca M et al. Guidelines 2.0: systematic development of a comprehensive checklist for a successful guideline enterprise. CMAJ 2014; 186: E123-E142

[41] James D, Warren-Forward H. Research methods for formal consensus development. Nurse Res 2015; 22: 35-40

[42] Frieden TR. Evidence for Health Decision Making - Beyond Randomized, Controlled Trials. N Engl J Med 2017; 377: 465-475

[43] Lenzer J, Hoffman JR, Furberg CD, Ioannidis JP.Guideline Panel Review Working G. Ensuring the integrity of clinical practice guidelines: a tool for protecting patients. BM] 2013; 347: f5535
[44] Schunemann HJ, Al-Ansary LA, Forland F, Kersten S, Komulainen J, Kopp IB, Macbeth F et al. Guidelines International Network: Principles for Disclosure of Interests and Management of Conflicts in Guidelines. Ann Intern Med 2015; 163: 548-553

[45] Semlitsch T, Blank WA, Kopp IB, Siering U, Siebenhofer A. Evaluating Guidelines: A Review of Key Quality Criteria. Dtsch Arztebl Int 2015; 112: 471-478

[46] Shaughnessy AF, Cosgrove L, Lexchin JR. The Need to Systematically Evaluate Clinical Practice Guidelines. J Am Board Fam Med 2016; 29: 644-648

[47] Neumann I, Santesso N, AkI EA, Rind DM, Vandvik PO, Alonso-Coello P, Agoritsas $T$ et al. A guide for health professionals to interpret and use recommendations in guidelines developed with the GRADE approach. J Clin Epidemiol 2016; 72: 45-55

[48] Shaneyfelt T. Pyramids are guides not rules: the evolution of the evidence pyramid. Evid Based Med 2016; 21: 121-122

[49] Guyatt GH, Oxman AD, Kunz R, Falck-Ytter Y, Vist GE, Liberati A, Schunemann $\mathrm{HJ}$ et al. Going from evidence to recommendations. BM] 2008; 336: 1049-1051

[50] Guyatt GH, Oxman AD, Kunz R, Vist GE, Falck-Ytter Y, Schunemann H], Group GW. What is "quality of evidence" and why is it important to clinicians? BMJ 2008; 336: 995-998

[51] Howick J, Chalmers I, Glasziou P, Greenhalgh T, Heneghan C, Liberati A, Moschetti I et al. The 2011 Oxford CEBM Levels of Evidence (Introductory Document). In.Oxford: Oxford Centre for Evidence-Based Medicine; 2011

[52] Welch VA, AkI EA, Guyatt G, Pottie K, Eslava-Schmalbach J, Ansari MT, de Beer $\mathrm{H}$ et al. GRADE equity guidelines 1 : Considering health equity in GRADE guideline development: Introduction and rationale. J Clin Epidemiol 2017; 90: 59-67

[53] Schunemann HJ, Oxman AD, Brozek J, Glasziou P, Jaeschke R, Vist GE, Williams JW Jr. et al. Grading quality of evidence and strength of recommendations for diagnostic tests and strategies. BMJ 2008; 336: $1106-1110$

[54] Brozek JL, Akl EA, Compalati E, Kreis J, Terracciano L, Fiocchi A, Ueffing $E$ et al. Grading quality of evidence and strength of recommendations in clinical practice guidelines part 3 of 3 . The GRADE approach to developing recommendations. Allergy 2011; 66: 588-595

[55] Andrews ], Guyatt G, Oxman AD, Alderson P, Dahm P, Falck-Ytter Y, Nasser $M$ et al.GRADE guidelines: 14 . Going from evidence to recommendations: the significance and presentation of recommendations. J Clin Epidemiol 2013; 66: 719-725

[56] Andrews JC, Schunemann H], Oxman AD, Pottie K, Meerpohl J], Coello PA, Rind D et al.GRADE guidelines: 15 . Going from evidence to recommendation-determinants of a recommendation's direction and strength. J Clin Epidemiol 2013; 66: 726-735

[57] Schunemann H], Wiercioch W, Brozek ], Etxeandia-lkobaltzeta I, Mustafa RA, Manja V, Brignardello-Petersen R et al. GRADE Evidence to Decision (EtD) frameworks for adoption, adaptation, and de novo development of trustworthy recommendations: GRADE-ADOLOPMENT. J Clin Epidemiol 2017; 81: 101-110

[58] Akl EA, Meerpohl J], Elliott J, Kahale LA, Schunemann H].Living Systematic Review N. Living systematic reviews: 4. Living guideline recommendations. J Clin Epidemiol 2017; 91: 47-53 